\title{
Communication
}

\section{Selective hydrogenation of benzene to cyclohexene in continuous reaction device with two reaction reactors in serie over $\mathrm{Ru}-\mathrm{Co}-\mathrm{B} / \mathrm{ZrO}_{2}$ catalysts}

\author{
Haijie Sun a,b, Shuaihui Li a , Yuanxin Zhang a , Houbing Jiang a, Lianglong Quc, Shouchang Liu, \\ Zhongyi Liu a,* \\ ${ }^{a}$ College of Chemistry and Molecular Engineering, Zhengzhou University, Zhengzhou 450001, Henan, China \\ ${ }^{\mathrm{b}}$ Institute of Environmental and Catalytic Engineering, Department of Chemistry, Zhengzhou Normal University, Zhengzhou 450044, Henan, China \\ ' Beijing Energy Engineering Technologies Co., Ltd, Beijing 100190, China
}

\section{A R T I C L E I N F O}

Article history:

Received 18 April 2013

Accepted 20 June 2013

Published 20 August 2013

Keywords:

Benzene

Selective hydrogenation

Cyclohexene

Ruthenium

Transition metal

Boron

\begin{abstract}
A B S T R A C T
$\mathrm{A} \mathrm{Ru}-\mathrm{B} / \mathrm{ZrO}_{2}$ catalyst for selective hydrogenation of benzene to cyclohexene was prepared using a chemical reduction method. The effects of transition metals such as $\mathrm{Cr}, \mathrm{Mn}, \mathrm{Fe}, \mathrm{Co}, \mathrm{Ni}, \mathrm{Cu}$, and $\mathrm{Zn}$ on the performance of the $\mathrm{Ru}-\mathrm{B} / \mathrm{ZrO}_{2}$ catalyst were investigated. It was found that the addition of these transition metals all increased the $\mathrm{B}$ content of the $\mathrm{Ru}-\mathrm{B} / \mathrm{ZrO}_{2}$ catalyst. The modification of $\mathrm{B}$, the ensemble effect, and the ligand effect of the second metal or metal oxide resulted in a decrease in the activity and an increase in the selectivity for cyclohexene of the $\mathrm{Ru}-\mathrm{B} / \mathrm{ZrO}_{2}$ catalyst. When the atomic ratio of $\mathrm{Co} / \mathrm{Ru}$ was 0.06 , the $\mathrm{Ru}-\mathrm{Co}-\mathrm{B} / \mathrm{ZrO}_{2}$ catalyst gave a selectivity for cyclohexene of $82.8 \%$ and a cyclohexene yield of $62.8 \%$ at a benzene conversion of $75.8 \%$ at $25 \mathrm{~min}$. Moreover, the benzene conversion was stable at around $40 \%$, and the selectivity for cyclohexene and the cyclohexene yields stabilized at around $73 \%$ and $30 \%$, respectively, in $419 \mathrm{~h}$ under the optimum reaction conditions in a continuous device with two reactors in series.
\end{abstract}

(C) 2013, Dalian Institute of Chemical Physics, Chinese Academy of Sciences. Published by Elsevier B.V. All rights reserved.
The production of nylon- 6 and nylon- 66 from benzene via cyclohexene has the advantages of safety, atomic economy, and being environmentally friendly, compared with the use of benzene and cyclohexane [1,2]. Supported amorphous alloy $\mathrm{Ru}$ catalysts have attracted much attention because they not only exhibit high activities and high selectivities for cyclohexene but also have the merits of better utilization of the Ru noble metal and ease of use in industry [3-6].

In our preliminary work, with the help of the enterprises, our group investigated the activity, cyclohexene selectivity, modifiable character, regeneration, and life-time of a
$\mathrm{Ru}-\mathrm{La}-\mathrm{B} / \mathrm{ZrO}_{2}$ catalyst in a series device with a $100 \mathrm{~L}$ stainless-steel autoclave $[7,8]$. In this device, the $\mathrm{Ru}-\mathrm{La}-\mathrm{B} / \mathrm{ZrO}_{2}$ catalyst gave a better performance than the $\mathrm{Ru}-\mathrm{Zn}$ catalyst obtained from the Asahi Chemical Company. However, the benzene conversion and the selectivity for cyclohexene were only $20 \%$ and $55 \%$, respectively, because of device defects. In this work, the effects of transition metals as promoters on the performance of the $\mathrm{Ru}-\mathrm{B} / \mathrm{ZrO}_{2}$ catalyst were systematically investigated. The $\mathrm{Ru}-\mathrm{Co}-\mathrm{B} / \mathrm{ZrO}_{2}$ catalyst with the optimum $\mathrm{Co} / \mathrm{Ru}$ molar ratio of 0.06 gave high activity and the best cyclohexene yield. Moreover, the performance of the $\mathrm{Ru}-\mathrm{Co}-\mathrm{B} / \mathrm{ZrO}_{2}$ catalyst for selective

\footnotetext{
*Corresponding author. Tel/Fax: +86-371-67783384; E-mail: liuzhongyi@zzu.edu.cn

This work was supported by the National Natural Science Foundation of China (21273205), the Innovation Found for Technology Based Firms of China (10C26214104505), the China Postdoctoral Science Foundation (2012M511125), and the Scientific Research Foundation of Graduate School of Zhengzhou University.
}

DOI: 10.1016/S1872-2067(12)60637-8 | http://www.sciencedirect.com/science/journal/18722067 | Chin. J. Catal., Vol. 34, No. 8, August 2013 
hydrogenation of benzene to cyclohexene was tested for the first time in a continuous device with two reactors in series.

The catalysts were prepared according to the procedure reported in the literature [9]. The preparation procedure for the $\mathrm{Ru}-\mathrm{Co}-\mathrm{B} / \mathrm{ZrO}_{2}$ catalyst is given as an example. $\mathrm{ZrO}_{2}(7.0 \mathrm{~g})$ was added to $200 \mathrm{~mL}$ of a solution containing $2.90 \mathrm{~g}$ of $\mathrm{RuCl}_{3} \cdot 3 \mathrm{H}_{2} \mathrm{O}$ and a desired amount of $\mathrm{CoCl}_{2} \cdot 6 \mathrm{H}_{2} \mathrm{O}$, with stirring; agitation was continued for $30 \mathrm{~min}$. To this suspension, $100 \mathrm{~mL}$ of $\mathrm{NaBH}_{4}$ solution $(0.8 \mathrm{~mol} / \mathrm{L})$ were quickly added dropwise under stirring at room temperature; stirring was continued for 5 min. The black precipitate was filtered and washed thoroughly with distilled water until neutrality, giving the desired $\mathrm{Ru}-\mathrm{Co}-\mathrm{B} / \mathrm{ZrO}_{2}$ catalyst. The catalyst was divided into two portions; one portion was used for activity tests and the other was used for catalyst characterization. This method ensured that catalysts promoted with the different transition metals had the same Ru contents (about $0.5 \mathrm{~g}$ ). The amount of $\mathrm{CoCl}_{2} \cdot 6 \mathrm{H}_{2} \mathrm{O}$ was adjusted to give catalysts with different nominal $\mathrm{Co} / \mathrm{Ru}$ molar ratios; these catalysts were denoted by $\mathrm{Ru}-\mathrm{Co}(x)-\mathrm{B} / \mathrm{ZrO}_{2}$, where $x$ is the nominal $\mathrm{Co} / \mathrm{Ru}$ molar ratio. The $\mathrm{Ru}-\mathrm{M}-\mathrm{B} / \mathrm{ZrO}_{2}$ catalysts were prepared in a manner similar to that used to prepare the $\mathrm{Ru}-\mathrm{Co}-\mathrm{B} / \mathrm{ZrO}_{2}$ catalysts, excepted that $\mathrm{CoCl}_{2} \cdot 6 \mathrm{H}_{2} \mathrm{O}$ was replaced by equal molar amounts of $\mathrm{Cr}\left(\mathrm{NO}_{3}\right)_{2} \cdot 6 \mathrm{H}_{2} \mathrm{O}$, $\mathrm{MnSO}_{4} \cdot \mathrm{H}_{2} \mathrm{O}, \quad \mathrm{FeSO}_{4} \cdot 7 \mathrm{H}_{2} \mathrm{O}, \quad \mathrm{NiSO}_{4} \cdot 7 \mathrm{H}_{2} \mathrm{O}, \quad \mathrm{CuSO}_{4} \cdot 5 \mathrm{H}_{2} \mathrm{O}$, or $\mathrm{ZnSO}_{4} \cdot 7 \mathrm{H}_{2} \mathrm{O}$. $\mathrm{Ru}-\mathrm{M}(x)-\mathrm{B} / \mathrm{ZrO}_{2}$ denotes the $\mathrm{Ru}-\mathrm{B} / \mathrm{ZrO}_{2}$ catalysts promoted with different transition metals, where $x$ represents the nominal M/Ru molar ratio.

The compositions of the catalysts were analyzed by inductively coupled plasma-atomic emission spectroscopy (ICP-AES) using an ICAT 6000 Series instrument (Heme Electron Corporation).

The selective hydrogenation of benzene was performed in a $1 \mathrm{~L}$ Hastelloy-lined autoclave. A sample of $\mathrm{Ru}-\mathrm{M}(x)-\mathrm{B} / \mathrm{ZrO}_{2}$ catalyst, $49.2 \mathrm{~g}$ of $\mathrm{ZnSO}_{4} \cdot 7 \mathrm{H}_{2} \mathrm{O}$, and $280 \mathrm{~mL}$ of water were charged in the autoclave. Heating was begun under a $\mathrm{H}_{2}$ pressure of 5 $\mathrm{MPa}$ and a stirring rate of $800 \mathrm{r} / \mathrm{min}$. Benzene $(140 \mathrm{~mL})$ was fed into the system and the stirring rate was increased to 1400 $\mathrm{r} / \mathrm{min}$ to exclude diffusion effects. The reaction process was monitored by taking small samples of the reaction mixture every $5 \mathrm{~min}$. The products were analyzed using gas chromatography (GC; Hangzhou Kexiao Instruments Co., GC-1690).

The performance of $\mathrm{Ru}-\mathrm{Co}(0.06)-\mathrm{B} / \mathrm{ZrO}_{2}$ was tested in a continuous device with two reactors in series according to the following procedure. A schematic diagram of the device is shown in Fig. 1. Each reactor has a capacity of $300 \mathrm{~L}$ and is made of Hastelloy. Ru-Co(0.06)-B/ZrO 2 catalyst $(5 \mathrm{~kg}), 500 \mathrm{~L}$ of water, and $88 \mathrm{~kg}$ of $\mathrm{ZnSO}_{4} \cdot 7 \mathrm{H}_{2} \mathrm{O}$ were added to reactors 1 and 2 from the catalyst feed inlet 5 and the catalyst holding tank 6 . The autoclave was purged four times with $\mathrm{N}_{2}$ to remove air that entered through the $\mathrm{N}_{2}$ inlet 2 . Then the $\mathrm{N}_{2}$ was flushed out four times using $\mathrm{H}_{2}$ through the $\mathrm{H}_{2}$ inlet 1 . The slurry circulation pump 10 was started with a slurry cycling speed of 647 $\mathrm{L} / \mathrm{h}$ under a $\mathrm{H}_{2}$ pressure of $5 \mathrm{MPa}$ and a stirring rate of 300 $\mathrm{r} / \mathrm{min}$. The benzene feed pump 4 was started with a benzene feeding speed of $150 \mathrm{~L} / \mathrm{h}$ when the temperature reached 140 ${ }^{\circ} \mathrm{C}$. After separation of the organic phase and the slurry in the settling tank, the slurry was pumped into reactor 1 by the slur-

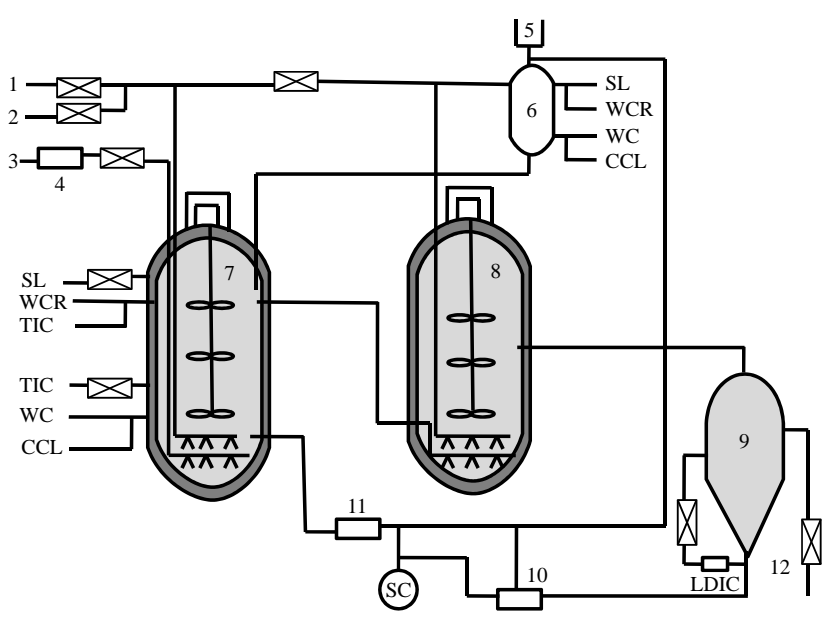

Fig. 1. Schematic diagram of the continuous reaction device with two reaction reactors in series. $1-\mathrm{H}_{2}$ inlet; $2-\mathrm{N}_{2}$ inlet; $3-$ benzene feed inlet; 4-benzene feed pump; 5-catalyst feed inlet; 6-catalyst holding tank; 7-reactor 1; 8-reactor 2; 9-settling tank; 10-slurry circulation pump; 11-slurry flow meter; 12-product outlet; $-\infty-$ - control valve; SL-low-pressure steam; WCR-returning cooling water; TIC-temperature indication controller; WC-cooling water; CCL-low-pressure circumfluent condensate; LDIC-level difference indication controller; $\mathrm{SC}$-solenoid-controlled valve.

ry cycling pump 10 . The temperature was controlled at $140 \pm$ $5^{\circ} \mathrm{C}$. The organic phase was sampled hourly, followed by GC analysis.

Table 1 shows the benzene conversions and selectivities for cyclohexene at the maximum yield in $25 \mathrm{~min}$ over the $\mathrm{Ru}-\mathrm{M}(\mathrm{x})-\mathrm{B} / \mathrm{ZrO}_{2}$ catalysts. As can be seen, the $\mathrm{Ru}-\mathrm{B} / \mathrm{ZrO}_{2}$ catalyst gave a selectivity for cyclohexene of $72.8 \%$ and a cyclohexene yield of $61.1 \%$ at a benzene conversion of $83.9 \%$ in the $1 \mathrm{~L}$ Hastelloy-lined autoclave. This indicates that the $\mathrm{Ru}-\mathrm{B} / \mathrm{ZrO}_{2}$ catalyst inherently exhibited a high activity and excellent selectivity for cyclohexene in the absence of any promoter. The activities of the $\mathrm{Ru}-\mathrm{M}(\mathrm{x})-\mathrm{B} / \mathrm{ZrO}_{2}$ catalysts all decreased, and the selectivities for cyclohexene all increased, with increasing

\section{Table 1}

Benzene conversions and selectivities for cyclohexene at maximum yield at 25 min over $\mathrm{Ru}-\mathrm{M}(x)-\mathrm{B} / \mathrm{ZrO}_{2}$ catalysts.

\begin{tabular}{lccc}
\hline Catalyst & Conversion (\%) & Selectivity (\%) & Yield (\%) \\
\hline $\mathrm{Ru}-\mathrm{B} / \mathrm{ZrO}{ }_{2}$ & 83.9 & 72.8 & 61.1 \\
$\mathrm{Ru}-\mathrm{Cr}(0.06)-\mathrm{B} / \mathrm{ZrO}_{2}$ & 44.0 & 82.4 & 36.3 \\
$\mathrm{Ru}-\mathrm{Cr}(0.21)-\mathrm{B} / \mathrm{ZrO}_{2}$ & 24.1 & 84.3 & 20.3 \\
$\mathrm{Ru}-\mathrm{Mn}(0.06)-\mathrm{B} / \mathrm{ZrO}_{2}$ & 69.6 & 78.5 & 54.6 \\
$\mathrm{Ru}-\mathrm{Mn}(0.21)-\mathrm{B} / \mathrm{ZrO}_{2}$ & 64.3 & 80.0 & 51.4 \\
$\mathrm{Ru}-\mathrm{Fe}(0.06)-\mathrm{B} / \mathrm{ZrO}_{2}$ & 53.5 & 80.9 & 43.3 \\
$\mathrm{Ru}-\mathrm{Fe}(0.21)-\mathrm{B} / \mathrm{ZrO}_{2}$ & 28.6 & 89.9 & 25.7 \\
$\mathrm{Ru}-\mathrm{Co}(0.06)-\mathrm{B} / \mathrm{ZrO}_{2}$ & 75.8 & 82.8 & 62.8 \\
$\mathrm{Ru}-\mathrm{Co}(0.21)-\mathrm{B} / \mathrm{ZrO}_{2}$ & 68.8 & 81.4 & 56.0 \\
$\mathrm{Ru}-\mathrm{Ni}(0.06)-\mathrm{B} / \mathrm{ZrO}_{2}$ & 50.4 & 81.7 & 41.1 \\
$\mathrm{Ru}-\mathrm{Ni}(0.21)-\mathrm{B} / \mathrm{ZrO}_{2}$ & 31.5 & 85.9 & 27.1 \\
$\mathrm{Ru}-\mathrm{Cu}(0.06)-\mathrm{B} / \mathrm{ZrO}_{2}$ & 50.9 & 85.3 & 43.4 \\
$\mathrm{Ru}-\mathrm{Cu}(0.21)-\mathrm{B} / \mathrm{ZrO}_{2}$ & 22.9 & 90.1 & 20.6 \\
$\mathrm{Ru}-\mathrm{Zn}(0.06)-\mathrm{B} / \mathrm{ZrO}_{2}$ & 76.4 & 76.8 & 58.6 \\
$\mathrm{Ru}-\mathrm{Zn}(0.21)-\mathrm{B} / \mathrm{ZrO}_{2}$ & 60.4 & 82.4 & 49.7 \\
\hline
\end{tabular}

Reaction conditions: in the $1 \mathrm{~L}$ Hastelloy-lined autoclave, a share of catalyst with the Ru content of about $0.5 \mathrm{~g}$, $45.7 \mathrm{~g} \mathrm{ZnSO}{ }_{4} \cdot 7 \mathrm{H}_{2} \mathrm{O}, 280 \mathrm{~mL}$ $\mathrm{H}_{2} \mathrm{O}, 5 \mathrm{MPa} \mathrm{H}, 150^{\circ} \mathrm{C}$, stirring rate of $1400 \mathrm{r} / \mathrm{min}$. 
amount of the second transition metal added. Obviously, the increase in cyclohexene selectivity is at the expense of catalytic activity, which is consistent with reports in the literature $[1,10]$. When the nominal $\mathrm{Co} / \mathrm{Ru}$ molar ratio was 0.06 , the activity of the $\mathrm{Ru}-\mathrm{Co}-\mathrm{B} / \mathrm{ZrO}_{2}$ catalyst decreased slightly, but the selectivity for cyclohexene significantly increased. Moreover, the best cyclohexene yield, i.e., $62.8 \%$, was obtained over this catalyst. The addition of $\mathrm{Cr}, \mathrm{Mn}, \mathrm{Fe}, \mathrm{Co}, \mathrm{Ni}, \mathrm{Cu}$, or $\mathrm{Zn}$ resulted in increased selectivity for cyclohexene, but the activities of the catalysts decreased significantly. The cyclohexene yields obtained using the catalysts with these transition metals as promoters were lower than that obtained using $\mathrm{Ru}-\mathrm{B} / \mathrm{ZrO}_{2}$.

Table 2 shows the compositions of the Ru-M-B/ZrO ${ }_{2}$ catalysts determined using ICP-AES. As can be seen, increasing the amounts of transition metals used as promoters increased the $\mathrm{B}$ contents of the catalysts, indicating that the added transition metals could adjust the B contents in the catalysts. It is known that the B content is an important factor in catalysts for selective hydrogenation of benzene to cyclohexene $[9,11,12]$. The B species in the Ru catalysts are mainly present in two forms: the elemental state and the oxidative state. The role of $B$ species can be understood based on the following considerations. (1) The oxidative B species on the catalyst surface could bond with water molecules through hydrogen bonds. This significantly enhances the hydrophilicity of the catalyst, which could accelerate desorption and hinder re-adsorption of cyclohexene for hydrogenation to cyclohexane. The selectivity for cyclohexene is therefore improved $[9,12]$. (2) The elemental B species could donate electrons to the Ru species, making the $\mathrm{B}$ species electron deficient and the $\mathrm{Ru}$ species electron rich. The electron-deficient B species could easily accept the lone pair on the oxygen in water [12], promoting water adsorption on the catalyst surface. This increases the hydrophilicity of the catalyst and improves the selectivity for cyclohexene. In addition, the electron-rich $\mathrm{Ru}$ species are also beneficial for the desorption of cyclohexene. The adsorption of water on the catalyst surface and the electron-rich Ru species could also prevent adsorption of benzene, resulting in decreased catalytic activity.

The ensemble effect and the ligand effect of the transition metals or metal oxides also have significant effects on the per-

Table 2

Compositions of $\mathrm{Ru}-\mathrm{M}-\mathrm{B} / \mathrm{ZrO}_{2}$ catalysts measured by ICP-AES.

\begin{tabular}{lcc}
\hline Catalyst & B content (wt\%) & M content (wt\%) \\
\hline $\mathrm{Ru}-\mathrm{B} / \mathrm{ZrO} \mathrm{w}_{2}$ & 0.065 & 0 \\
$\mathrm{Ru}-\mathrm{Cr}(0.06)-\mathrm{B} / \mathrm{ZrO}_{2}$ & 0.277 & 0.282 \\
$\mathrm{Ru}-\mathrm{Cr}(0.21)-\mathrm{B} / \mathrm{ZrO}_{2}$ & 0.331 & 0.655 \\
$\mathrm{Ru}-\mathrm{Mn}(0.06)-\mathrm{B} / \mathrm{ZrO}_{2}$ & 0.144 & 0.441 \\
$\mathrm{Ru}-\mathrm{Mn}(0.21)-\mathrm{B} / \mathrm{ZrO}_{2}$ & 0.205 & 0.985 \\
$\mathrm{Ru}-\mathrm{Fe}(0.06)-\mathrm{B} / \mathrm{ZrO}_{2}$ & 0.118 & 0.108 \\
$\mathrm{Ru}-\mathrm{Fe}(0.21)-\mathrm{B} / \mathrm{ZrO}_{2}$ & 0.221 & 1.196 \\
$\mathrm{Ru}-\mathrm{Co}(0.06)-\mathrm{B} / \mathrm{ZrO}_{2}$ & 0.152 & 0.124 \\
$\mathrm{Ru}-\mathrm{Co}(0.21)-\mathrm{B} / \mathrm{ZrO}_{2}$ & 0.181 & 0.761 \\
$\mathrm{Ru}-\mathrm{Ni}(0.06)-\mathrm{B} / \mathrm{ZrO}_{2}$ & 0.129 & 0.186 \\
$\mathrm{Ru}-\mathrm{Ni}(0.21)-\mathrm{B} / \mathrm{ZrO}_{2}$ & 0.207 & 0.734 \\
$\mathrm{Ru}-\mathrm{Cu}(0.06)-\mathrm{B} / \mathrm{ZrO}_{2}$ & 0.078 & 0.266 \\
$\mathrm{Ru}-\mathrm{Cu}(0.21)-\mathrm{B} / \mathrm{ZrO}_{2}$ & 0.100 & 1.337 \\
$\mathrm{Ru}-\mathrm{Zn}(0.06)-\mathrm{B} / \mathrm{ZrO}_{2}$ & 0.078 & 0.437 \\
$\mathrm{Ru}-\mathrm{Zn}(0.21)-\mathrm{B} / \mathrm{ZrO}_{2}$ & 0.321 & 1.813 \\
\hline
\end{tabular}

formances of the catalysts in selective hydrogenation of benzene to cyclohexene. The ensemble effect means that the presence of transition metals or metal oxides could cause a geometric arrangement of the $\mathrm{Ru}$ active sites and might reduce or dilute $\mathrm{Ru}$ active sites for the hydrogenation of cyclohexene to cyclohexane, resulting in increased selectivity for cyclohexene [10]. The ligand effect means that the presence of transition metals or metal oxides could enhance the catalyst hydrophilicity, leading to a decrease in the adsorption enthalpies for $\mathrm{H}_{2}$, benzene, or cyclohexene. The selectivities of the catalysts for cyclohexene therefore increase [10]. Struijk et al. [13] proposed that chemisorbed $\mathrm{Zn}^{2+}$ could not only increase the catalyst hydrophilicity but could also selectively cover the most reactive sites. This decreased the adsorption enthalpies of benzene and cyclohexene, increasing the desorption rate and the selectivity for cyclohexene. Fan et al. [4] prepared a $\mathrm{Ru}-\mathrm{Co}-\mathrm{B} / \gamma-\mathrm{Al}_{2} \mathrm{O}_{3}$ catalyst and found that the Co promoter improved the selectivity for cyclohexene. They found that the Co species existed in the catalyst as oxides, and suggested that the presence of Co oxides could create a micro-environment that was unfavorable for further hydrogenation of cyclohexene to cyclohexane. Specifically, the Co oxides could occupy the active sites, on which cyclohexene is quickly hydrogenated to cyclohexane. The selectivity for cyclohexene therefore increases. Also, there is electron transfer from Ru species to the Co oxides [4]. The adsorbability of cyclohexene on the electron-deficient $\mathrm{Ru}$ is weak, and it is easy for cyclohexene to be desorbed from the catalyst surface, and so the selectivity for cyclohexene increases $[4,14]$. The addition of a second metal or metal oxide therefore improves the selectivity of the $\mathrm{Ru}-\mathrm{B} / \mathrm{ZrO}_{2}$ catalyst.

Obviously, $\mathrm{Co}$ is the best promoter for the $\mathrm{Ru}-\mathrm{B} / \mathrm{ZrO}_{2}$ catalyst; it significantly increased the selectivity for cyclohexene and the cyclohexene yield, and slightly decreased the activity. The $\mathrm{Ru}-\mathrm{Co}(0.06)-\mathrm{B} / \mathrm{ZrO}_{2}$ catalyst gave the best cyclohexene yield as a result of the synergistic effects among the active component $\mathrm{Ru}$, the Co promoter, and the $\mathrm{B}$ species.

The effect of the stirring rate on the performance of the $\mathrm{Ru}-\mathrm{Co}(0.06)-\mathrm{B} / \mathrm{ZrO}_{2}$ catalyst was investigated at a benzene feeding rate of $200 \mathrm{~L} / \mathrm{h}$ and a slurry cycling rate of $647 \mathrm{~L} / \mathrm{h}$. The results are summarized in Fig. 2(a). Increasing the stirring rate increased the selectivity for cyclohexene and the cyclohexene yield, but decreased the activity. When the stirring rate was $450 \mathrm{r} / \mathrm{min}$, the benzene conversion was stable at around $45 \%$, and the selectivity for cyclohexene and the cyclohexene yield stayed at around $73 \%$ and $33 \%$, respectively. This indicates that mass transport limitation at the gas/liquid interface and the liquid/liquid interface is minimized at a stirring rate of 450 $\mathrm{r} / \mathrm{min}$. However, further increasing the stirring rate to 500 $\mathrm{r} / \mathrm{min}$ decreased the benzene conversion and the cyclohexene yield. This suggests that the higher stirring rate prevented the mass transport of benzene or $\mathrm{H}_{2}$, resulting in a decrease in the reaction rate. Struijk et al. [15] also observed the same phenomenon. They thought that the catalysts easily suffered from attrition and adhesion to the inner wall of the reactor.

The effect of the benzene feeding rate on the performance of the $\mathrm{Ru}-\mathrm{Co}(0.06)-\mathrm{B} / \mathrm{ZrO}_{2}$ catalyst was investigated at a stirring rate of $450 \mathrm{r} / \mathrm{min}$ and a slurry cycling rate of $647 \mathrm{~L} / \mathrm{h}$. The re- 

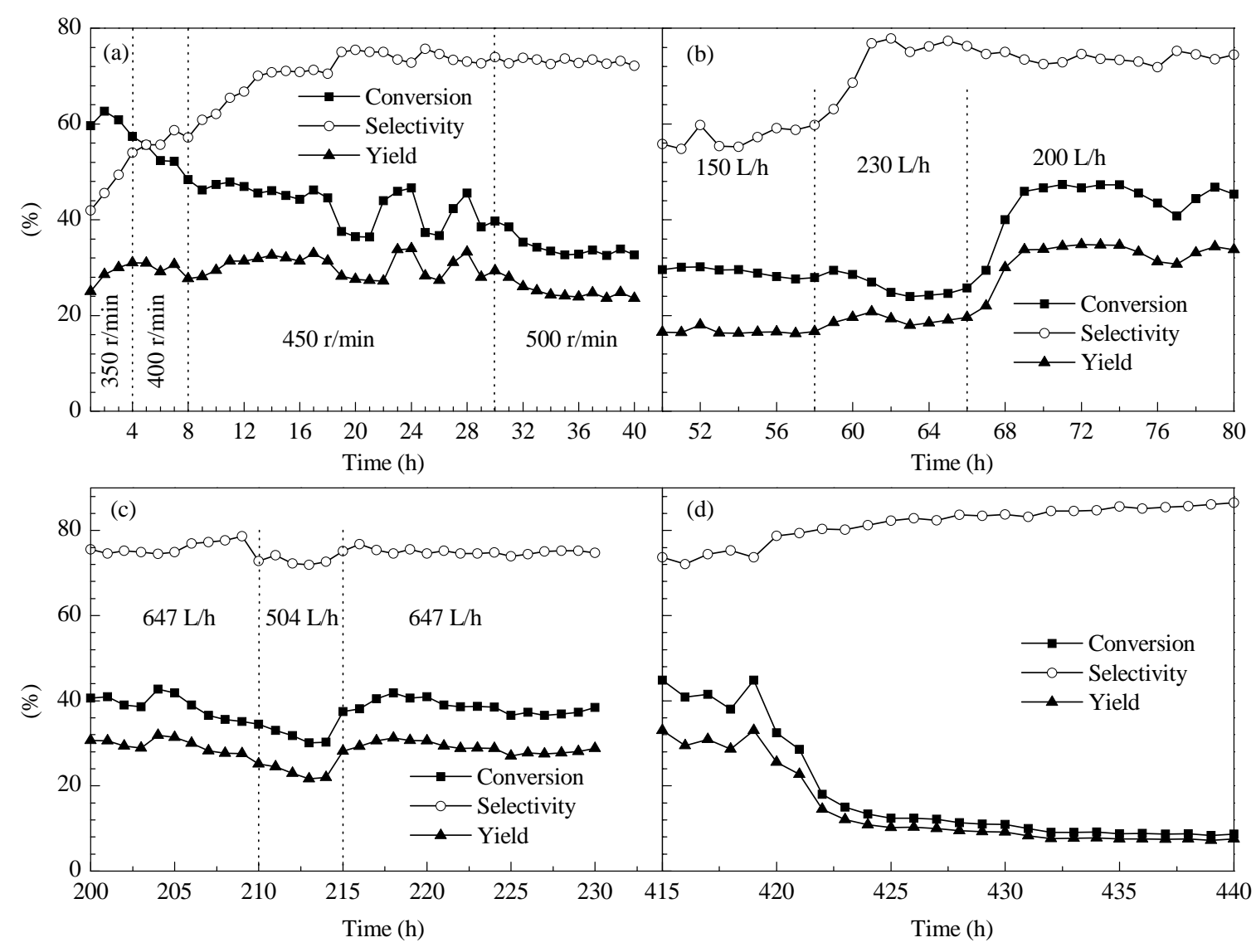

Fig. 2. Performance of $\mathrm{Ru}-\mathrm{Co}(0.06)-\mathrm{B} / \mathrm{ZrO}_{2}$ catalyst for selective hydrogenation of benzene to cyclohexene in a continuous reaction device with two reactors in series. (a) Effect of stirring rate; (b) Effect of benzene feeding rate; (c) Effect of slurry cycling rate; (d) Catalyst stability under optimum conditions. Reaction conditions: catalyst $5 \mathrm{~kg}$, water $500 \mathrm{~L}, \mathrm{ZnSO}_{4} \cdot 7 \mathrm{H}_{2} \mathrm{O} 88 \mathrm{~kg}, 140 \pm 5^{\circ} \mathrm{C}, 4.5 \pm 0.5 \mathrm{MPa} \mathrm{H}_{2}$.

sults are shown in Fig. 2(b). When the benzene feeding rate was increased from 150 to $230 \mathrm{~L} / \mathrm{h}$, the benzene conversion slightly decreased, but the selectivity for cyclohexene and the cyclohexene yield gradually increased. Increasing the benzene feeding rate could promote the desorption of cyclohexene dissolved in benzene and increase the selectivity for cyclohexene. When the benzene feeding rate was decreased from 230 to $200 \mathrm{~L} / \mathrm{h}$, although the selectivity for cyclohexene decreased slightly, the benzene conversion and the cyclohexene yield increased significantly. This indicates that the optimum benzene feeding rate was $200 \mathrm{~L} / \mathrm{h}$, at which the catalyst provided a higher cyclohexene yield and a higher reaction rate.

The effect of the slurry cycling rate on the performance of the $\mathrm{Ru}-\mathrm{Co}(0.06)-\mathrm{B} / \mathrm{ZrO}_{2}$ catalyst was investigated at a stirring rate of $450 \mathrm{r} / \mathrm{min}$ and a benzene feeding rate of $200 \mathrm{~L} / \mathrm{h}$. The results are shown in Fig. 2(c). When the slurry cycling rate was decreased from 647 to $504 \mathrm{~L} / \mathrm{h}$, the benzene conversion, the selectivity for cyclohexene, and the cyclohexene yield all decreased. This indicates that increasing the slurry cycling rate favors mass transport of the reactants, i.e., benzene and $\mathrm{H}_{2}$, improving the reaction rate. Moreover, increasing the slurry cycling rate is also beneficial for the desorption of cyclohexene, so the selectivity for cyclohexene increased. However, the slurry cycling rate could not be increased further because of limitations imposed by the volume of the settling tank.

The stability and lifetime of $\mathrm{Ru}-\mathrm{Co}(0.06)-\mathrm{B} / \mathrm{ZrO}_{2}$ were in- vestigated at a stirring rate of $450 \mathrm{r} / \mathrm{min}$, a benzene feeding rate of $200 \mathrm{~L} / \mathrm{h}$, and a slurry cycling rate of $647 \mathrm{~L} / \mathrm{h}$. The results are shown in Fig. 2(d). The benzene conversion stabilized at around $40 \%$, and the selectivity for cyclohexene and the cyclohexene yield remained at around $73 \%$ and $30 \%$, respectively, up to $419 \mathrm{~h}$; this is close to the cyclohexene yield of $32 \%$ achieved with an industrial Ru-Zn catalyst. However, it should be noted that the $\mathrm{Ru}$ content of $\mathrm{Ru}-\mathrm{Co}(0.06)-\mathrm{B} / \mathrm{ZrO}_{2}$ was only one-quarter that of the industrial $\mathrm{Ru}-\mathrm{Zn}$ catalyst. This indicates that the $\mathrm{Ru}-\mathrm{Co}(0.06)-\mathrm{B} / \mathrm{ZrO}_{2}$ catalyst not only has excellent selectivity for cyclohexene and good stability but also has better noble metal utilization. The mass ratio of benzene/Ru was 0.26 in the $1 \mathrm{~L}$ autoclave, but it was only 0.12 in the continuous device. The performance of $\mathrm{Ru}-\mathrm{Co}(0.06)-\mathrm{B} / \mathrm{ZrO}_{2}$ in the continuous device did not reach the same level as that in the $1 \mathrm{~L}$ autoclave because of the limitations of the continuous device (such as defects in the settling tank). The benzene conversion and cyclohexene yields decreased significantly. The Zn and Fe contents in the catalyst were $2.17 \%$ and $0.57 \%$, respectively, determined using ICP-AES, indicating that the chemisorption of large amounts of $\mathrm{Zn}^{2+}$ and $\mathrm{Fe}^{2+}$ led to deactivation of the catalyst. It was found that large areas of the walls of reactors 1 and 2 were corroded, as shown in Fig. 3, and this was the main source of $\mathrm{Fe}^{2+}$. However, the activity and the selectivity of the catalyst for cyclohexene were recovered by washing out the chemisorbed $\mathrm{Zn}^{2+}$ and $\mathrm{Fe}^{2+}$ with $\mathrm{HCl}$ solution [8]. 


\title{
Graphical Abstract
}

Chin. J. Catal., 2013, 34: 1482-1488 doi: 10.1016/S1872-2067(12)60637-8

Selective hydrogenation of benzene to cyclohexene in continuous reaction device with two reaction reactors in serie over $\mathrm{Ru}-\mathrm{Co}-\mathrm{B} / \mathrm{ZrO}_{2}$ catalysts

Haijie Sun, Shuaihui Li, Yuanxin Zhang, Houbing Jiang, Lianglong Qu, Shouchang Liu, Zhongyi Liu*

Zhengzhou University;

Zhengzhou Normal University;

Beijing Energy Engineering Technologies Co., Ltd

The selectivity for cyclohexene and the cyclohexene yield were stabilized at around $73 \%$ and $30 \%$, respectively, in 419 h over a Ru-Co-B/ZrO 2 catalyst in a continuous device with two reactors in series.

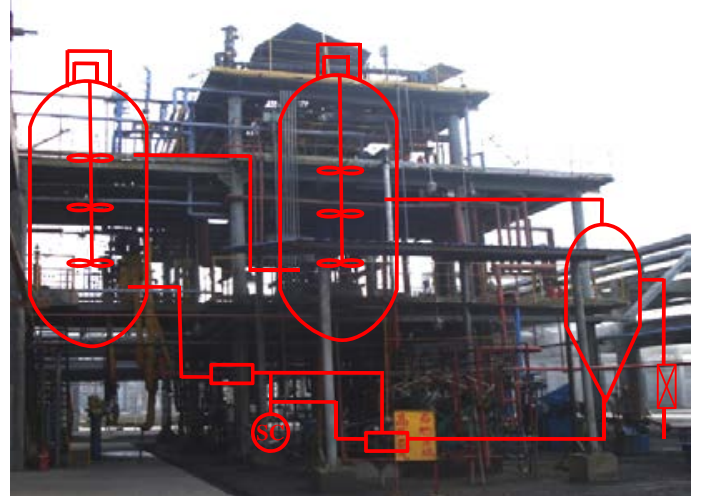

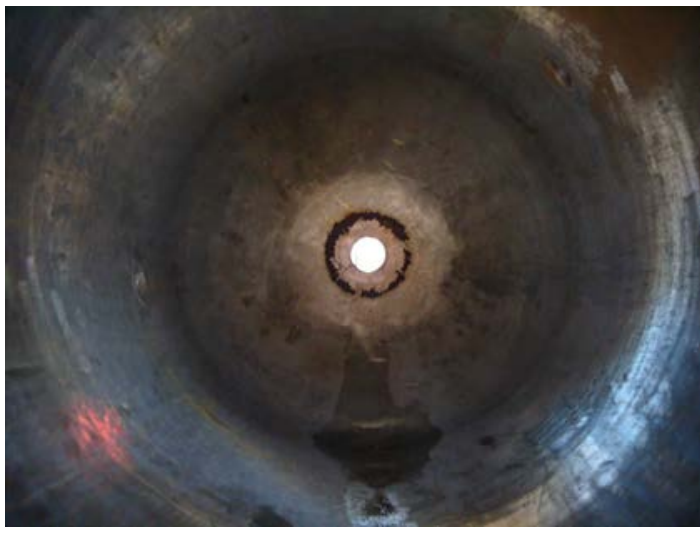

Fig. 3. Deeply corroded reactor.

In summary, the $\mathrm{Ru}-\mathrm{Co}(0.06)-\mathrm{B} / \mathrm{ZrO}_{2}$ catalyst exhibited excellent selectivity for cyclohexene and good stability, indicating its good prospects for industrial applications. It was found that the activity and the selectivity of the catalyst for cyclohexene in a continuous device with two reactors in series were higher than those achieved using a single reactor $[7,8]$. One of the biggest advantages of the continuous device with two reactors in series is enlargement of the reactor volume, which enables the slurry cycling rate and the benzene feeding rate to be increased. This results in good contact between benzene and the catalyst, and improved desorption of cyclohexene, increasing the catalytic activity and selectivity for cyclohexene.

\section{References}

[1] Sun H J, Wang H X, Jiang H B, Li S H, Liu S C, Liu Z Y, Yuan X M, Yang K J. Appl Catal A, 2013, 450: 160

[2] Sun H J, Jiang H B, Li S H, Wang H X, Pan Y J, Dong Y Y, Liu S C. Chin J Catal (孙海杰, 江厚兵, 李帅辉, 王红霞, 潘雅洁, 董英英, 刘寿长, 刘仲毅. 催化学报), 2013, 34: 684

[3] Fan G Y, Li R X, Li X J, Chen Hua. Catal Commun, 2008, 9: 1394

[4] Fan G Y, Jiang W D, Wang J B, Li R X, Li X J. Catal Commun, 2008, 10: 98

[5] Zhao Y J, Zhou J, Zhang J G, Wang S D. Catal Commun, 2008, 9: 459

[6] Xue W, Qin Y F, Li F, Wang Y J, Wang Z M. Chin J Catal (薛伟, 秦燕 飞, 李芳, 王延吉, 王志苗. 催化学报), 2012, 33: 1913

[7] Liu S C, Liu Z Y, Wang Z, Zhao S H, Wu Y M. Appl Catal A, 2006, 313: 49

[8] Liu S C, Liu Z Y, Wang Z, Wu Y M, Yuan P. Chem Eng J, 2008, 139: 157

[9] Sun H J, Zhang C, Yuan P, Li J X, Liu S C. Chin J Catal (孙海杰, 张程, 袁鹏, 李建修, 刘寿长. 催化学报), 2008, 29: 441

[10] Schwab F, Lucas M, Claus P. Angew Chem Int Ed, 2011, 50: 10453

[11] Liu Z, Dai W L, Liu B, Deng J F. J Catal, 1999, 187: 253

[12] Xie S H, Qiao M H, Li H X, Wang W J, Deng J F. Appl Catal A, 1999, 176: 129

[13] Struijk J, Moene R, van der Kamp T, Scholten J J F. Appl Catal A, 1992, 89: 77

[14] Mazzieri V A, L'Argentiere P C, Coloma-Pascual F, Figoli N S. Ind Eng Chem Res, 2003, 42: 2269

[15] Struijk J, d'Angremond M, Regt W J M L, Scholten J J F. Appl Catal A, 1992, 83: 263

\section{串联双釜连续反应装置中Ru-Co-B/ $/ \mathrm{ZrO}_{2}$ 上苯选择加氢制环己烯}

\author{
孙海杰, ${ }^{\mathrm{a}, \mathrm{b}}$, 李帅辉 ${ }^{\mathrm{a}}$, 张元馨 ${ }^{\mathrm{a}}$, 江厚兵 ${ }^{\mathrm{a}}$, 曲良龙 ${ }^{\mathrm{c}}$, 刘寿长 ${ }^{\mathrm{a}}$, 刘仲毅 ${ }^{\mathrm{a}}$,* \\ a 郑州大学化学与分子工程学院, 河南郑州 450001 \\ b 郑州师范学院化学系, 环境与催化工程研究所, 河南郑州450044 \\ “北京安耐吉能源工程技术有限公司，北京100190
}

摘要: 采用化学还原法制备了苯选择加氢制环己烯催化剂 Ru-B/ZrO $\mathrm{Zr}_{2}$, 考察了 $\mathrm{Cr}, \mathrm{Mn}, \mathrm{Fe}, \mathrm{Co}, \mathrm{Ni}, \mathrm{Cu}$ 和 $\mathrm{Zn}$ 等过渡金属的添加对 
$\mathrm{Ru}-\mathrm{B} / \mathrm{ZrO}_{2}$ 催化剂性能的影响. 结果表明, 这些过渡金属的添加均可提高 $\mathrm{Ru}-\mathrm{B} / \mathrm{ZrO}_{2}$ 催化剂中的 $\mathrm{B}$ 含量. $\mathrm{B}$ 的修饰及第二种金属或 金属氧化物的集团效应和配位效应导致 $\mathrm{Ru}-\mathrm{B} / \mathrm{ZrO}_{2}$ 催化剂活性降低和环己烯选择性升高. 当 $\mathrm{Co} / \mathrm{Ru}$ 原子比为 0.06 时, $\mathrm{Ru}-\mathrm{Co}-\mathrm{B} / \mathrm{ZrO} \mathrm{r}_{2}$ 催化剂上反应 $25 \mathrm{~min}$ 苯转化率为 $75.8 \%$ 时, 环己烯选择性和收率分别为 $82.8 \%$ 和 $62.8 \%$. 在双釜串联连续反应器中和优化反应条件 下, Ru-Co-B/ZrO 2 催化剂使用 $419 \mathrm{~h}$ 内苯转化率稳定在 $40 \%$ 左右, 环已烯选择性和收率分别稳定在 $73 \%$ 和 $30 \%$ 左右.

关键词: 苯; 选择加氢; 环已烯; 钉; 过渡金属; 硼

收稿日期: 2013-04-18. 接受日期: 2013-06-20. 出版日期: 2013-08-20.

*通讯联系人. 电话/传真: (0371)67783384; 电子信箱: liuzhongyi@zzu.edu.cn

基金来源：国家自然科学基金(21273205); 国家科技型中小企业创新基金(10C26214104505); 中国博士后科学基金 (2012M511125); 郑州大学优秀博士论文培育基金.

本文的英文电子版由Elsevier出版社在ScienceDirect上出版(http://www.sciencedirect.com/science/journal/18722067).

由苯出发经环己烯制备尼龙6和尼龙66比经环己烷 路线具有安全、碳原子经济和环境友好等特点 ${ }^{[1,2]}$. 化学 还原法制备的负载型非晶态合金Ru基催化剂不但在苯 选择加氢反应中表现出高活性和高环已烯选择性, 而且 具有贵金属利用率高和易工业化等优点, 引起了人们的 极大关注 $^{[3-6]}$.

本课题组曾与企业联合, 在 $100 \mathrm{~L}$ 不锈钢单釜连续 反应装置上考察了 $\mathrm{Ru}-\mathrm{La}-\mathrm{B} / \mathrm{ZrO}_{2}$ 催化剂的活性、环己烯 选择性、可调变性、再生和寿命等重要指标 ${ }^{[7,8]}$, 发现该 催化剂性能明显优于进口Ru-Zn催化剂. 然而由于反应 装置的原因, 苯转化率仅为 $20 \%$, 环己烯选择性仅为 $55 \%$. 本文系统考察了过渡金属对 $\mathrm{Ru}-\mathrm{B} / \mathrm{ZrO}_{2}$ 催化剂性 能的影响, 并在串联双釜连续反应器中考察了 $\mathrm{Ru}-\mathrm{Co}-\mathrm{B} / \mathrm{ZrO}_{2}$ 催化剂的苯选择加氢制环己烯性能.

参照文献 [9] 制备催化剂. 在搅拌下将 $2.90 \mathrm{~g}$ $\mathrm{RuCl}_{3} \cdot 3 \mathrm{H}_{2} \mathrm{O}$ 和一定量的 $\mathrm{CoCl}_{2} \cdot 6 \mathrm{H}_{2} \mathrm{O}$ 溶于 $200 \mathrm{~mL}$ 水中, 加 入 $7.0 \mathrm{~g} \mathrm{ZrO}_{2}$, 继续摚拌 $30 \mathrm{~min}$; 于室温快速滴入 $100 \mathrm{~mL}$ $\mathrm{NaBH}_{4}$ 溶液 $(0.8 \mathrm{~mol} / \mathrm{L})$. 滴加完毕后, 继续搅拌 $5 \mathrm{~min}$. 然后抽滤至洗涤液为中性, 即得 Ru-Co-B/ZrO 2 催化剂. 平均分为 2 份, 分别用于催化剂评价和表征, 确保用于加 氢的各催化剂中 $\mathrm{Ru}$ 含量相同 $(0.5 \mathrm{~g})$. 调整 $\mathrm{CoCl}_{2} \cdot 6 \mathrm{H}_{2} \mathrm{O}$ 用 量, 制得不同 $\mathrm{Co} / \mathrm{Ru}$ 原子比的 $\mathrm{Ru}-\mathrm{Co}(x)-\mathrm{B} / \mathrm{ZrO}{ }_{2}$, 其中 $x$ 为 $\mathrm{Co} / \mathrm{Ru}$ 理论原子比. 以同样方法制得 $\mathrm{Ru}-\mathrm{M}(x)-\mathrm{B} / \mathrm{ZrO}_{2}$ 催 化剂( $\mathrm{M}=\mathrm{Cr}, \mathrm{Mn}, \mathrm{Fe}, \mathrm{Co}, \mathrm{Ni}, \mathrm{Cu}$ 或 Zn), 各金属 $\mathrm{M}$ 的前驱 体分别为 $\mathrm{Cr}\left(\mathrm{NO}_{3}\right)_{3} \cdot 9 \mathrm{H}_{2} \mathrm{O}, \mathrm{MnSO}_{4} \cdot \mathrm{H}_{2} \mathrm{O}, \mathrm{FeSO}_{4} \cdot 7 \mathrm{H}_{2} \mathrm{O}$, $\mathrm{NiSO}_{4} \cdot 7 \mathrm{H}_{2} \mathrm{O}, \mathrm{CuSO}_{4} \cdot 5 \mathrm{H}_{2} \mathrm{O}$ 和 $\mathrm{ZnSO}_{4} \cdot 7 \mathrm{H}_{2} \mathrm{O}$.

催化剂组成在 Heme Electron公司的 ICAT 6000 SERIES型电感耦合等离子原子发射光谱仪(ICP-AES)上 测定.

$\mathrm{Ru}-\mathrm{M}(\mathrm{x})-\mathrm{B} / \mathrm{ZrO}_{2}$ 催化剂评价在1 L GS-1型哈氏合金 釜中进行. 加入一份 Ru-M-B/ZrO 2 催化剂, $49.2 \mathrm{~g}$ $\mathrm{ZnSO}_{4} \cdot 7 \mathrm{H}_{2} \mathrm{O}$ 和 $280 \mathrm{~mL} \mathrm{H} \mathrm{H}_{2} \mathrm{O}$. 在 $5 \mathrm{MPa} \mathrm{H}_{2}$ 压力和 800 $\mathrm{r} / \mathrm{min}$ 转速下升温至 $150{ }^{\circ} \mathrm{C}$ 后加入 $140 \mathrm{~mL}$ 苯, 调节转速至
$1400 \mathrm{r} / \mathrm{min}$, 每隔5 min取样, 在GC-1690型气相色谱仪(杭 州科晓)上分析产物组成.

串联双釜连续反应器(见图1)中 $\mathrm{Ru}-\mathrm{Co}(0.06)-\mathrm{B} / \mathrm{ZrO}_{2}$ 催化剂评价按如下步骤进行. 每个反应釜的体积为 300 $\mathrm{L}$, 釜材质为哈氏合金. 从催化剂进口5和催化剂储藏罐 6 将 $5 \mathrm{~kg} \mathrm{Ru}-\mathrm{Co}(0.06)-\mathrm{B} / \mathrm{ZrO}_{2}$ 催化剂、 $500 \mathrm{~L}$ 水和 $88 \mathrm{~kg}$ $\mathrm{ZnSO}_{4} \cdot 7 \mathrm{H}_{2} \mathrm{O}$ 加入到反应器 1 和 2 中. 通过氮气进气口 2 , 用氮气置换釜内空气 4 次, 再经氢气进气口 1 , 用氢气置 换釜内氮气 4次. 调节 $\mathrm{H}_{2}$ 压至 $5 \mathrm{MPa}$, 转速 $300 \mathrm{r} / \mathrm{min}$. 开 启浆液循环洜 10 , 调节浆液循环速率为 $647 \mathrm{~L} / \mathrm{h}$. 升温至 $140{ }^{\circ} \mathrm{C}$ 后, 开启苯进料洜 4 , 苯进料流量为 $150 \mathrm{~L} / \mathrm{h}$. 有机 相与浆液在沉降槽 $(770 \mathrm{~L})$ 分离后, 浆液经浆液循环洜 10 打入反应釜1. 控制反应温度在 $140 \pm 5{ }^{\circ} \mathrm{C}$. 每隔 $1 \mathrm{~h}$ 取样. 在GC-1690型气相色谱仪上分析产物组成.

表1给出了 $\mathrm{Ru}-\mathrm{M}-\mathrm{B} / \mathrm{ZrO}_{2}$ 催化剂上反应 $25 \mathrm{~min}$ 内最 高环己烯收率时苯转化率和环己烯选择性. 可以看出, 在 $1 \mathrm{~L}$ 哈氏合金釜中 $\mathrm{Ru}-\mathrm{B} / \mathrm{ZrO}_{2}$ 上苯转化率为 $83.9 \%$ 时环 己烯选择性和收率分别为 $72.8 \%$ 和 $61.1 \%$, 说明不加任何 助剂的 Ru-B/ $/ \mathrm{ZrO}_{2}$ 催化剂具有较高的活性和环己烯选择 性. 随着过渡金属的加入及其量的增加, 催化剂活性降 低, 环己烯选择性升高. 可见, 环己烯选择性的升高是以 牺牲活性为代价的, 与文献 $[1,10]$ 一致. 当 $\mathrm{Co} / \mathrm{Ru}$ 原子比 为 0.06 时, Ru-Co-B/ $/ \mathrm{ZrO}_{2}$ 催化剂的活性略有下降, 环己烯 选择性则显著升高, 其收率达 $62.8 \%$; 而第二助剂 $\mathrm{Cr}$, $\mathrm{Mn}, \mathrm{Fe}, \mathrm{Co}, \mathrm{Ni}, \mathrm{Cu}$ 和Zn的加入则使环己烯选择性升高 的同时, 反应活性显著降低, 环已烯收率也更低.

表2为 Ru-M-B/ZrO 催化剂的组成. 可以看出, 随着 第二种助剂含量的增加, 催化剂中 $\mathrm{B}$ 含量增加, 说明所加 过渡金属可以调节催化剂中的 $\mathrm{B}$ 含量, 而 $\mathrm{B}$ 含量是影响 苯选择加氢制环己烯催化剂性能的重要因素 ${ }^{[9,11,12]}$. Ru 催化剂中 $\mathrm{B}$ 主要以游离态和氧化态两种形式存在. 氧化 态的 $\mathrm{B}$ 可以通过氢键与水分子键合, 提高催化剂的亲水 性, 加速生成环己烯的脱附, 抑制脱附环己烯的再吸附 
并加氢生成环己烷, 环已烯选择性增加 ${ }^{[9,12]}$. 游离态的 $\mathrm{B}$ 可以将部分电子转移给 $\mathrm{Ru}$, 使得 $\mathrm{B}$ 缺电子, $\mathrm{Ru}$ 富电子. 缺 电子的B更容易接受水中 $\mathrm{O}$ 的孤对电子, 促进了 $\mathrm{H}_{2} \mathrm{O}$ 在催 化剂表面的吸附, 因而催化剂亲水性增强, 环已烯选择 性升高. 富电子的Ru有利于生成的环己烯脱附. 另外, 水的吸附和 $\mathrm{Ru}$ 的富电子又抑制了苯在催化剂表面上的 吸附, 从而导致催化剂活性降低 ${ }^{[12]}$.

第二种助剂金属或金属氧化物的集团效应和配位 体效应也是影响苯选择加氢制环己烯催化剂性能的另 一个重要因素. 集团效应是指第二助剂金属或金属氧化 物的存在导致活性组分金属Ru的几何重排, 减少或稀释 了环已烯加氢的Ru活性位, 从而提高环已烯选择性 ${ }^{[10]}$. 配位效应为第二助剂金属或金属氧化物的存在增加了 $\mathrm{Ru}$ 催化剂亲水性, 使得 $\mathrm{H}_{2}$ 、苯或环已烯化学吸附焓降低, 因而环己烯选择性升高 ${ }^{[10]}$. Struijk等 ${ }^{[13]}$ 认为, 化学吸附 的 $\mathrm{Zn}^{2+}$ 不但可以增加催化剂亲水性, 而且可以选择覆盖 一部分最强的活性位, 从而降低苯和环己烯在催化剂表 面的吸附焓, 提高环己烯的脱附速率, 增大环已烯选择 性. Fan等 ${ }^{[4]}$ 制备了 Ru-Co-B $/ \gamma-\mathrm{Al}_{2} \mathrm{O}_{3}$ 催化剂, 发现Co可提 高环已烯选择性. 他们发现催化剂中Co以氧化物存在, 从而创造了一个不利于环已烯继续加氢的微环境. 首先 氧化钴可以占据环己烯很快加氢的活性位, 因而环己烯 选择性升高; 其次, Ru可以将部分电子转移给氧化钴 ${ }^{[4]}$, 缺电子的 Ru上环已烯吸附能力差, 易脱附, 因而环己烯 选择性升高 ${ }^{[4,14]}$. 总之, 第二助剂金属或金属氧化物的 加入提高了环已烯选择性.

综上可见, $\mathrm{Co}$ 的加入显著提高了 $\mathrm{Ru}-\mathrm{B} / \mathrm{ZrO}_{2}$ 催化剂 上环已烯选择性和收率(62.8\%), 其活性略有下降, 促进 效果最佳.

在苯进料速率和浆液循环速率分别为 200 和 $647 \mathrm{~L} / \mathrm{h}$ 的条件下, 考察了搅拌速率对 $\mathrm{Ru}-\mathrm{Co}(0.06)-\mathrm{B} / \mathrm{ZrO}_{2}$ 催化 剂性能的影响, 结果见图2(a). 可以看出, 随着搅拌速率 的增加, 苯转化率逐渐降低, 环已烯选择性和收率逐渐 升高; 至 $450 \mathrm{r} / \mathrm{min}$ 时苯转化率稳定在 $45 \%$ 左右, 环己烯 选择性和收率分别稳定在 $73 \%$ 和 $33 \%$ 左右, 表明在 450 $\mathrm{r} / \mathrm{min}$ 时气-液和液-液之间界面的传质阻力最小. 继续增 加搅拌速率至 $500 \mathrm{r} / \mathrm{min}$, 苯转化率和环已烯收率降低, 表明较快的搅拌抑制了气-液和液-液界面的传质, 使得 反应速率下降, 与文献[15]一致. 在较高的搅拌下催化
剂易破损, 且易粘附在反应器壁上.

在搅拌速率和浆液循环速率分别为 $450 \mathrm{r} / \mathrm{min}$ 和 647 $\mathrm{L} / \mathrm{h}$ 的条件下, 考察了苯进料速率对 $\mathrm{Ru}-\mathrm{Co}(0.06)-\mathrm{B} / \mathrm{ZrO}_{2}$ 催化剂性能的影响, 结果见图2(b). 可以看出, 当苯进料 速率从 $150 \mathrm{~L} / \mathrm{h}$ 升至 $230 \mathrm{~L} / \mathrm{h}$, 苯转化率略有下降, 但环己 烯选择性和收率逐渐提高. 苯进料速率的提高有利于溶 解在苯中的环已烯溢出, 因此选择性增加. 当苯进料速 率又降低至 $200 \mathrm{~L} / \mathrm{h}$, 虽然环已烯选择性略有降低, 但苯 转化率和环已烯收率显著提高. 可见, 苯进料速率控制 在 $200 \mathrm{~L} / \mathrm{h}$ 为宜.

在搅拌速率和苯进料速率分别为 $450 \mathrm{r} / \mathrm{min}$ 和 200 $\mathrm{L} / \mathrm{h}$ 的条件下, 考察了浆液循环速率对 Ru-Co(0.06)-B/ $\mathrm{ZrO}_{2}$ 催化剂性能的影响, 结果见图2(c). 当浆液循环量 由 $647 \mathrm{~L} / \mathrm{h}$ 降至 $504 \mathrm{~L} / \mathrm{h}$ 时, 苯转化率、环己烯选择性和收 率均降低, 表明较高的浆液循环速率不但有利于反应物 苯和 $\mathrm{H}_{2}$ 的传质, 提高了反应速率, 而且有利于环已烯的 溢出, 提高环已烯选择性. 然而浆液循环量受制于沉降 槽的体积.

图2(d)给出了 $\mathrm{Ru}-\mathrm{Co}(0.06)-\mathrm{B} / \mathrm{ZrO}_{2}$ 催化剂的稳定性 和寿命. 可以看出, 反应 $419 \mathrm{~h}$ 以前, 苯转化率稳定在 40\%左右, 环已烯选择性和收率分别稳定在 $73 \%$ 和 $30 \%$ 左右, 后者与目前工业催化剂的接近(32\%). 但本催化剂 中 $\mathrm{Ru}$ 用量仅为工业 Ru-Zn 催化剂的 1/4. 可见， $\mathrm{Ru}-\mathrm{Co}(0.06)-\mathrm{B} / \mathrm{ZrO}_{2}$ 催化剂不但具有较高的环己烯选择 性和稳定性, 而且贵金属利用率高. 需要特别指出的是, 小试中苯 $/ \mathrm{Ru}$ 质量比为 0.26 , 而串联双釜中苯/ $\mathrm{Ru}$ 质量比 仅为 0.12 , 同时由于反应釜条件的限制(如沉降槽的设计 缺陷等), $\mathrm{Ru}-\mathrm{Co}(0.06)-\mathrm{B} / \mathrm{ZrO}_{2}$ 催化剂性能并未达到单釜 $(1 \mathrm{~L})$ 水平. 另外, 反应 $419 \mathrm{~h}$ 以后苯转化率和环已烯收率 急剧降低. ICP测得 Ru-Co(0.06)-B/ $/ \mathrm{ZO}_{2}$ 中 $\mathrm{Zn}$ 和Fe含量分 别为 $2.17 \%$ 和 $0.57 \%$, 说明大量化学吸附的 $\mathrm{Zn}^{2+}$ 和 $\mathrm{Fe}^{2+}$ 导 致了催化剂的失活. 打开反应釜, 发现反应器壁大面积 腐蚀, 如图3所示, 这是 $\mathrm{Fe}^{2+}$ 的主要来源. 然而, 用 $\mathrm{HCl}$ 洗 去化学吸附的 $\mathrm{Fe}^{2+}$ 和 $\mathrm{Zn}^{2+}$ 可恢复催化剂活性和选择性 ${ }^{[6]}$.

总之, 在串联双釜连续反应装置中, 反应容积明显 增加, 因而 Ru-Co(0.06)-B/ $\mathrm{ZrO}_{2}$ 催化剂在苯选择加氢反 应中表现出较高的活性和选择性, 明显优于单釜连续反 应装置 ${ }^{[7,8]}$, 且具有良好的稳定性, 具有较大的工业应用 潜力. 